\title{
Atypical Mitotic Figures
}

National Cancer Institute

\section{Source}

National Cancer Institute. Atypical Mitotic Figures. NCI Thesaurus. Code C35962.

A morphologic finding indicating the presence of atypical mitoses in malignant cells. 